\title{
Lack of resistance to macrolides in Mycoplasma genitalium detected in South African pregnant women
}

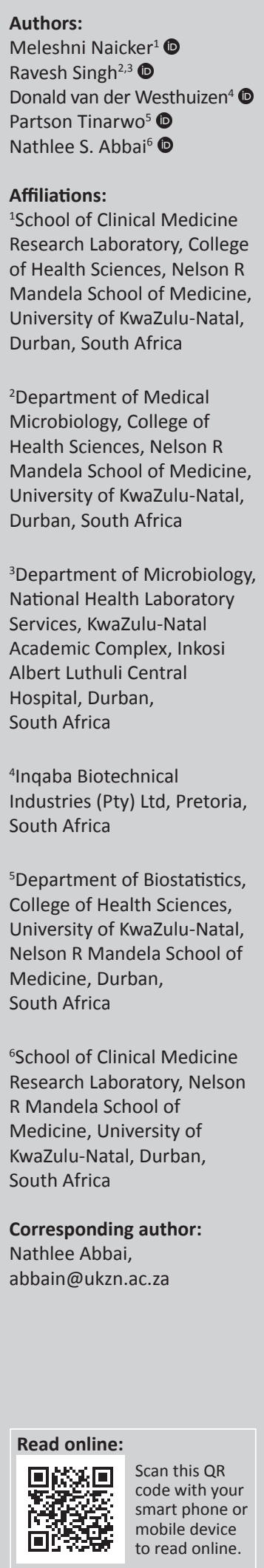

Background: Azithromycin regimens have been considered first-line treatment for Mycoplasma genitalium (M. genitalium), a sexually transmitted infection (STI) associated with adverse pregnancy outcomes. However, recent years have seen rapid emergence of macrolide resistance in $M$. genitalium as a result of widespread administration of azithromycin. Currently, there are limited data on macrolide resistance in pregnant women from KwaZulu-Natal (KZN), South Africa. This study investigated the prevalence of M. genitalium and emerging patterns of macrolide resistance in pregnant women from KZN.

Methods: This was a sub-study of a larger study which involved laboratory-based detection of STIs in pregnant women. In the main study, pregnant women provided urine samples for detection of STIs. For this study, deoxyribose nucleic acid (DNA) extracted from stored urine was used to determine emerging macrolide resistance by amplification of the $23 S$ ribosomal ribonucleic acid ( $r R N A$ ) gene of $M$. genitalium by polymerase chain reaction (PCR) and sequencing of amplicons to identify mutations associated with resistance. The Allplex ${ }^{\mathrm{TM}} \mathrm{MG}$ \& AziR assay was used as a confirmatory assay.

Results: The prevalence of M. genitalium in pregnant women was 5.9\% (13 out of 221). Sequencing of PCR amplicons did not reveal the presence of the A2059G and A2058G mutations associated with macrolide resistance. These findings were confirmed by the Allplex ${ }^{\mathrm{TM}} \mathrm{MG} \&$ AziR assay.

Conclusion: Despite the lack of resistance to macrolides in this study population, continued antimicrobial resistance surveillance for M. genitalium in pregnant women is important because azithromycin is now part of the South African national STI syndromic management guidelines for vaginal discharge syndrome.

Keywords: Mycoplasma genitalium; pregnant women; azithromycin; macrolide resistance; $23 S$ rRNA gene mutations; KwaZulu-Natal.

\section{Introduction}

Mycoplasma genitalium (M. genitalium) is an emerging sexually transmitted infection (STI) that is associated with non-gonococcal urethritis (NGU) in men $^{1,2}$ and cervicitis in women. ${ }^{2,3}$ In addition, genital mycoplasma infections in women have been implicated in various pathological conditions and upper genital tract complications during pregnancy, consequently giving rise to a host of adverse outcomes. These include pelvic inflammatory disease, endometritis, chorioamnionitis and postpartum fever, resulting in complications such as infertility, spontaneous abortion, stillbirth, preterm birth, low birth weight and perinatal mortality. ${ }^{4,5,6,7,8,9}$ However, there is still controversy regarding the role of $M$. genitalium in adverse pregnancy outcomes. ${ }^{10,11,12}$ Further, M. genitalium has been reported to be a possible contributing factor for the acquisition and transmission of human immunodeficiency virus (HIV). ${ }^{13,14}$ The prevalence of M. genitalium infection in women within the general population was reported between $1 \%$ and $4 \%$ but can reach $10 \%$ or higher in STI clinic attendees. ${ }^{15,16,17}$ In a study conducted in Pretoria, South Africa, in 2012 and 2016, the prevalence of M. genitalium in termination of pregnancy attendees was reported to be $6.0 \%$ in 2012 and $7.7 \%$ in $2016 .^{18}$

Current South African Sexually Transmitted Infections Management Guidelines (2015) recommend the administration of a single oral dose $(1 \mathrm{~g})$ of azithromycin for the treatment of

Dates: Received: 20 Apr. 2020 | Accepted: 21 Sept. 2020 | Published: 15 Jan. 2021

How to cite this article: Naicker M, Singh R, Van der Westhuizen D, Tinarwo P, Abbai NS. Lack of resistance to macrolides in Mycoplasma genitalium detected in South African pregnant women. S Afr J Infect Dis. 2021;36(1), a209. https://doi.org/10.4102/sajid.v36i1.209

Copyright: (c) 2021. The Authors. Licensee: AOSIS. This work is licensed under the Creative Commons Attribution License. 
vaginal discharge syndrome and male urethritis syndrome. ${ }^{19}$ However, recent years have seen the rapid emergence of macrolide resistance in $M$. genitalium as a result of this widespread administration of azithromycin. ${ }^{18,20,21,22,23,24,25}$ The genetic basis for macrolide resistance was reported to be as a result of mutations occurring at positions 2058 and 2059 (E. coli numbering) within the $\mathrm{V}$ region of the $23 \mathrm{~S}$ ribosomal ribonucleic acid ( $r R N A$ ) gene of $M$. genitalium. ${ }^{22}$

To date, there remains limited data available on the emergence of macrolide resistance in pregnant populations from KwaZulu-Natal (KZN). The present study provides data on the lack of macrolide resistance in pregnant women in our setting. In addition, this study provides data on the prevalence of $M$. genitalium in pregnant women, which is currently lacking in KZN.

\section{Materials and methods}

\section{Study population and samples}

The study was a sub-study of the larger study which involved laboratory-based detection of STIs in pregnant women (BE214/17). In the main study, pregnant women provided urine samples for detection of STIs. The women were recruited from the King Edward VIII Hospital in Durban, KZN, during the period November 2017 to April 2018. All enrolled women were 18 years and older, willing to provide written informed consent, information on their demographics, sexual behaviour, clinical information and a urine sample to be tested for vaginal infections.

Deoxyribose nucleic acid (DNA) was extracted from the urine using the PureLink ${ }^{\mathrm{TM}}$ Microbiome DNA Purification Kit (ThermoFisher Scientific, Massachusetts, USA) in accordance with the manufacturer's instructions. Unused DNA was stored at $-20^{\circ} \mathrm{C}$. For this sub-study, $n=221$ stored DNA samples were used to determine the presence of emerging resistance to macrolides amongst the participants.

\section{Detection of Mycoplasma genitalium from urine}

Commercially available primers and probes specific for M. genitalium (Ba04646249_sl) were used with the TaqMan quantitative polymerase chain reaction (qPCR) assay (ThermoFisher Scientific, USA). The assay was run on the Quant Studio 5 Real-time PCR detection system (ThermoFisher Scientific, USA). The PCR was performed in a final reaction volume of $5 \mu \mathrm{L}$ comprising: $0.25 \mu \mathrm{L}$ Fluorescein amidite (FAM)-labelled probe and/or primer mix, $1.25 \mu \mathrm{L}$ Fast Start $4 \mathrm{x}$ probe master mix (ThermoFisher, Part No. 4444434), $1.5 \mu \mathrm{L}$ template DNA and nuclease-free water. Non-template control reactions and positive controls (TaqMan $^{\mathrm{TM}}$ Vaginal Microbiota Extraction Control; cat no. A32039, ThermoFisher Scientific, USA) were also included. Amplification was performed at $95^{\circ} \mathrm{C}$ for $30 \mathrm{~s}$ followed by 45 cycles comprising of denaturation at $95{ }^{\circ} \mathrm{C}$ for $3 \mathrm{~s}$ and annealing at $60^{\circ} \mathrm{C}$ for $30 \mathrm{~s}$. Detection of amplified fluorescent products was carried out at the end of the annealing phase.
The raw fluorescent data included the $C_{T}$ mean values, which were automatically generated by the Quant Studio 5 Realtime PCR system software (ThermoFisher Scientific, USA).

\section{Detection of mutations in the 235 ribosomal ribonucleic acid gene conferring macrolide resistance}

Screening assay: Conventional polymerase chain reaction

Macrolide resistance-associated mutations in the $23 S$ rRNA gene were determined for all samples that tested positive for M. genitalium by the TaqMan assay. The unique 147 base pair (bp) region within the $23 S$ rRNA gene of M. genitalium, which flanks mutations found in the $\mathrm{V}$ region of the gene, was amplified and sequenced.22 The screening PCR was performed in a final volume of $25 \mu \mathrm{L}$ and comprised of 12.5 $\mu$ L Dream Taq (2x) master mix (ThermoFisher Scientific, USA), $1 \mu \mathrm{L}$ of each $(10 \mu \mathrm{M})$ primer, $5 \mu \mathrm{L}$ template DNA and nuclease-free water. Amplification was performed at an initial denaturation of $95^{\circ} \mathrm{C}$ for $2 \mathrm{~min}$, followed by 40 cycles of $95{ }^{\circ} \mathrm{C}$ for $30 \mathrm{~s}$ (denaturation), $54{ }^{\circ} \mathrm{C}$ for $1 \mathrm{~min}$ (annealing) and $72{ }^{\circ} \mathrm{C}$ for $1 \mathrm{~min}$ (extension). A final extension step at $72{ }^{\circ} \mathrm{C}$ for $5 \mathrm{~min}$ was included. Polymerase chain reaction amplicons were separated on 1\% gel electrophoresis and visualised using an ultraviolet transilluminator (Gene Genius, SYNGENE, Maryland, USA).

\section{Deoxyribose nucleic acid sequencing of amplicons}

The $147 \mathrm{bp}$ amplicon was sequenced using the Sanger method at Inqaba Biotechnological Industries in Pretoria, South Africa. The amplicons were sequenced using an ABI3500XL genetic analyser and the raw sequence data were edited using Chromas software V2.6.5 (Technelysium, Queensland, Australia) and then subjected to the National Centre for Biotechnology Information's (NCBI) Basic Local Alignment Search Tool (BLAST) function for identity confirmation of the amplicons. This was followed by a multiple sequence alignment of study samples - V172, V193 and V208 - with strains of known mutations, LA141 (HF572938.1), LA088 (HF572933.1) and LA202 (HF572946.1), and a strain that does not include the mutations, that is, M. genitalium G37 complete genome (L43967.2), using ClustalW (https://www.genome. jp/tools-bin/clustalw).

\section{Confirmatory assay - Allplex ${ }^{\text {TM }}$ MG \& AziR assay (Seegene)}

The Allplex ${ }^{\mathrm{TM}}$ MG \& AziR assay (Seegene, Seoul, South Korea) is a commercially available assay which allows for the simultaneous detection and identification of M. genitalium and six mutations (A2058C, A2058G, A2058T, A2059C, A2059G and $A 2059 T)$ responsible for azithromycin resistance on validated sample types, which include genital swabs, urine and liquidbased cytology samples. The testing was performed as per the kit instructions and the samples were run on the Bio-Rad CFX96 equipped with Seegene interpretative software.

\section{Statistical analyses}

The statistical analysis was conducted using $\mathrm{R}$ software (version 3.6.1), a freely available software environment for 
statistical computing. Initially, the population characteristics were described using frequencies stratified by infection status of the STI investigated. All the tests were conducted at $5 \%$ level of significance.

\section{Ethical consideration}

Ethical approval to conduct the study was obtained from the Biomedical Research Ethics Committee (BREC), University of KwaZulu-Natal (UKZN), (reference no. BE214/17).

\section{Results}

\section{Characteristics of the population according to Mycoplasma genitalium status}

Out of 221 samples, 13 tested positive for M. genitalium using the TaqMan assay. The prevalence of M. genitalium in the study population was $5.9 \%$. The median age of all 13 of the women who tested positive for M. genitalium was 26 years (interquartile range [IQR] 21-35). The analysis showed no significant associations ( $p>0.05)$ between socio-demographic, behavioural and clinical data with reference to M. genitalium status (Table 1). Despite the lack of statistical significance, more than $60 \%$ of the women who tested M. genitalium positive did not present with symptoms of abnormal vaginal discharge on the day of enrolment. Similarly, more than $75 \%$ of the women did not experience previous symptoms of STIs 3 months prior to the enrolment. All women who tested positive for M. genitalium $(n=13)$ were unmarried. More than half of these women (53.8\%) had reported having between two and four life-time sexual partners. A larger proportion of the positive women $(53.8 \%)$ had indicated that either their current sexual partners had no other partners, or they were not aware of their partners having other partners. With regard to behavioural practices, $84.6 \%$ of the $M$. genitalium positive women had not used a condom during their last sexual act. Clinically, the majority of women who tested positive were in the third trimester of pregnancy (53.8\%).

\section{Detection of macrolide resistance-associated mutations in the 235 ribosomal ribonucleic acid gene}

\section{Screening assay: Conventional polymerase chain reaction}

The $147 \mathrm{bp}$ fragment associated with the $23 S$ rRNA gene was detected in 8 out of 13 (61.5\%) of the M. genitalium positive isolates analysed. Sanger sequencing confirmed that the PCR amplicons obtained were the 23S rRNA gene from M. genitalium (Accession number: Mk411362.1). Samples which produced good sequencing reads were aligned with strains with known mutations as well as a strain which lacked the mutations. According to the multiple sequence alignment, positions of known mutations associated with macrolide resistance, that is, A2058G, A2059C and A2059G, were not present in the study samples analysed. Similarly, these mutations were not present in the G37 strain (strain lacking the mutations) (Figure 1). However, as expected, the A2058G mutation was present in strain LA141, the A2059G mutation was present in strain LA088 and the A2059C mutation was present in strain LA202 (Figure 1). The prevalence of macrolide resistant $M$. genitalium in our study population was $0 \%$.

\section{Confirmatory assay - Allplex ${ }^{\mathrm{TM}}$ MG \& AziR assay (Seegene)}

The Allplex ${ }^{\mathrm{TM}} \mathrm{MG} \& \mathrm{AziR}$ assay produced results for 11 out of 13 samples tested $(84.61 \%)$ showing that it is much more sensitive than the screening assay (conventional PCR). The conventional PCR detected the $23 S$ rRNA in $61.5 \%$ of the samples tested (Table 1-A1). Two of the study samples V014 and V069 did not produce a positive result for the presence of M. genitalium on the Allplex ${ }^{\mathrm{TM}} \mathrm{MG} \&$ AziR assay despite testing positive on the TaqMan assay and yielding the $147 \mathrm{bp}$ amplicon. The discrepancy between the assays may have been the result of loss of sample integrity (as a result of the freeze-thawing process) or loss of sample volume during shipment.

However, the Allplex ${ }^{\mathrm{TM}} \mathrm{MG} \& \mathrm{AziR}$ assay confirmed that the prevalence of macrolide resistant $M$. genitalium in our study population was $0 \%$. None of the study samples tested positive for any of the six mutations (A2058C, A2058G, A2058T, A2059C, A2059G and A2059T) responsible for azithromycin resistance (Table 2-A1). However, all assay controls yielded the expected results indicating that the results were valid.

\section{Discussion}

To the best of our knowledge, this is the first study to provide an estimate on the prevalence of $M$. genitalium in pregnant women from the Durban area in KZN, South Africa. We report a prevalence estimate of $5.9 \%$ for $M$. genitalium. Our data are consistent with previous reports on M. genitalium infection in South African pregnant women. ${ }^{18,26}$ Redelinghuys et al. (2013) reported a prevalence of $14.5 \%$ for M. genitalium in pregnant women from Gauteng, South Africa. ${ }^{26}$ Similarly, another study conducted by Le Roux et al. (2018) reported a prevalence of $6.0 \%$ in 2012 and 7.7\% in 2016 for M. genitalium in pregnant women from Pretoria, South Africa. ${ }^{18}$ In our study, the factors that could be attributed to this prevalence are as follows: $67.4 \%$ of the study women did not use condoms during their last sexual act; $61.5 \%$ were not living with their regular partner; $70.1 \%$ were unaware if their partner had other partners and $75.1 \%$ had first experienced sex between 15 and 20 years of age. In addition, 51.1\% had between two and four life-time sex partners and $43.4 \%$ were previously treated for STIs. Many of these factors have been shown to contribute to the prevalence of sexually acquired infections. . $^{27,28,29,30}$

The emergence of macrolide resistance in M. genitalium has drawn recent attention. ${ }^{18,20,21,22,23}$ The first study to report on macrolide resistance in $M$. genitalium in South Africa was conducted by Hay et al. in the Limpopo province of rural South Africa in 2015. ${ }^{20}$ In that study, the authors reported detecting macrolide resistance-associated mutations in 4 out of 41 (9.8\%) of M. genitalium positive isolates obtained from 
TABLE 1: Characteristics of the study population stratified by Mycoplasma genitalium status. Characteristics Mycoplasma genitalium infection

\begin{tabular}{|c|c|c|c|c|c|c|c|c|c|c|c|c|c|}
\hline & \multirow{2}{*}{\multicolumn{4}{|c|}{ Negative $(n=208)$}} & & & & & & & & & \\
\hline & & & & & \multicolumn{4}{|c|}{ Positive $(n=13)$} & \multicolumn{4}{|c|}{ Overall $(n=221)$} & \\
\hline & $n$ & $\%$ & Mean \pm SD & Median & $n$ & $\%$ & Mean \pm SD & Median & $n$ & $\%$ & Mean \pm SD & Median & \\
\hline Age & - & - & & - & - & - & - & - & - & - & - & - & 0.622 \\
\hline CV & - & 21.1 & $28.3 \pm 5.97$ & - & - & 26.7 & $28.0 \pm 7.47$ & - & - & 21.3 & $28.3 \pm 6.04$ & - & - \\
\hline Q1 & 28 & - & - & 24.0 & 26 & - & - & 21.0 & 27 & - & - & 24.0 & - \\
\hline Q3 & - & - & - & 33.0 & - & - & - & 35.0 & - & - & - & 33.0 & - \\
\hline Minimum-maximum & $18.0-43.0$ & - & - & - & $20.0-42.0$ & - & - & - & $18.0-43.0$ & - & - & - & - \\
\hline Current abnormal & - & - & - & - & - & - & - & - & - & - & - & - & 0.771 \\
\hline
\end{tabular}

Current abnormal

vaginal $d$

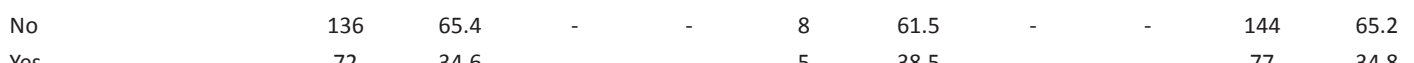

Yes

38.5

past 3 months

$\mathrm{N}$

Yes

$177 \quad 85.1$

$31 \quad 14.9$

Level of education

$13 \quad 06.2$

Primary and below

High school

$140 \quad 67.3$

College/University

$55 \quad 26.4$

Marital status

No

Yes

$175 \quad 84.5$

Has a regular sexual

$32 \quad 15.5$

partner

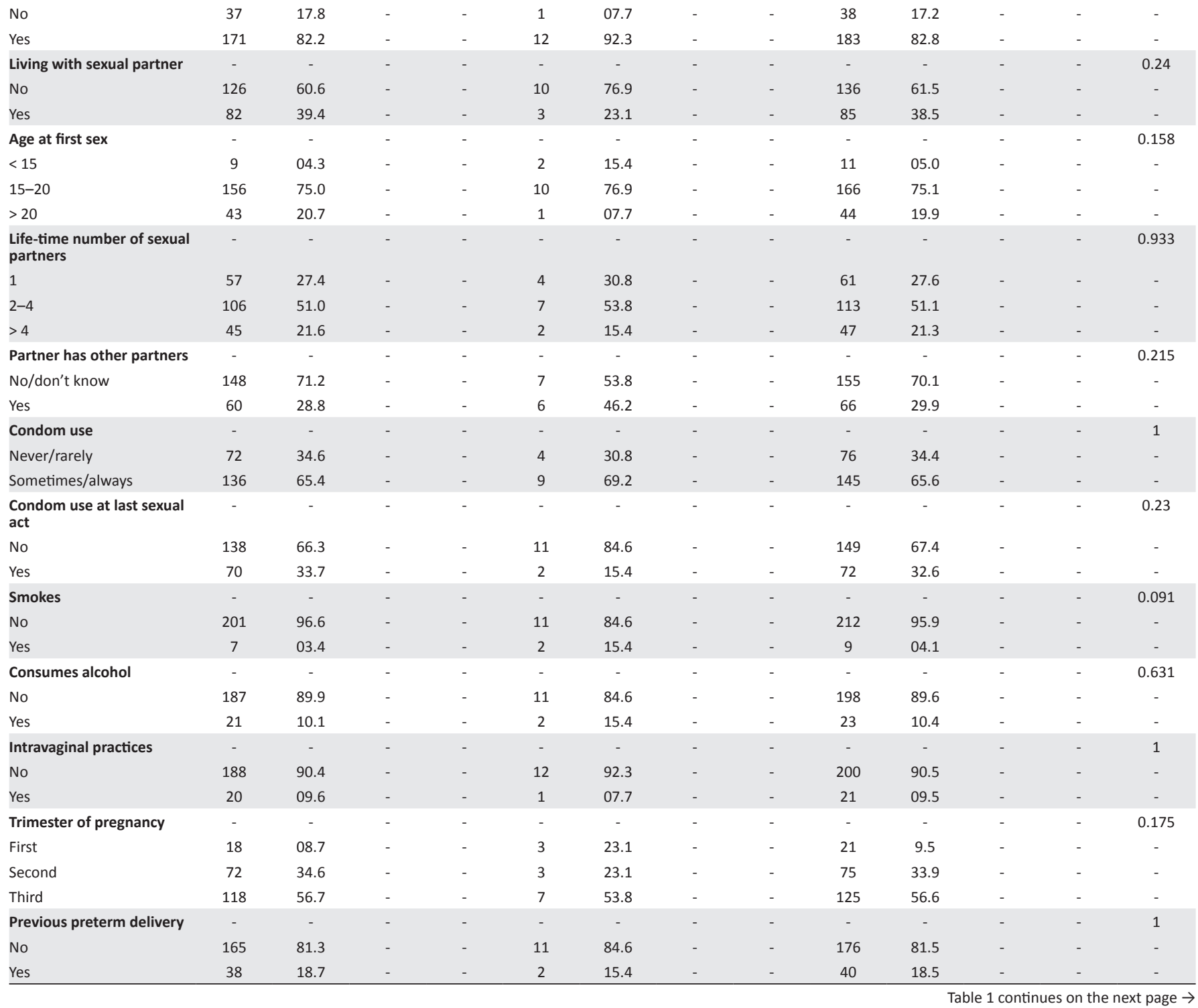


TABLE 1 (Continues...): Characteristics of the study population stratified by Mycoplasma genitalium status.

\begin{tabular}{|c|c|c|c|c|c|c|c|c|c|c|c|c|c|}
\hline \multirow[t]{3}{*}{ Characteristics } & \multicolumn{12}{|c|}{ Mycoplasma genitalium infection } & \multirow[t]{3}{*}{$p$} \\
\hline & \multicolumn{4}{|c|}{ Negative $(n=208)$} & \multicolumn{4}{|c|}{ Positive $(n=13)$} & \multicolumn{4}{|c|}{ Overall $(n=221)$} & \\
\hline & $n$ & $\%$ & Mean \pm SD & Median & $n$ & $\%$ & Mean \pm SD & Median & $n$ & $\%$ & Mean \pm SD & Median & \\
\hline Past miscarriage & - & - & - & - & - & - & - & - & - & - & - & - & 0.193 \\
\hline No & 150 & 72.1 & - & - & 12 & 92.3 & - & - & 162 & 73.3 & - & - & - \\
\hline Yes & 58 & 27.9 & - & - & 1 & 07.7 & - & - & 59 & 26.7 & - & - & - \\
\hline Past spontaneous abortion & - & - & - & - & - & - & - & - & - & - & - & - & 1 \\
\hline No & 189 & 90.9 & - & - & 12 & 92.3 & - & - & 201 & 91.0 & - & - & - \\
\hline Yes & 19 & 9.1 & - & - & 1 & 07.7 & - & - & 20 & 09.0 & - & - & - \\
\hline $\begin{array}{l}\text { Previous abnormal vaginal } \\
\text { discharge }\end{array}$ & - & - & - & - & - & - & - & - & - & - & - & - & 0.774 \\
\hline No & 119 & 57.2 & - & - & 8 & 61.5 & - & - & 127 & 57.7 & - & - & - \\
\hline Yes & 88 & 42.3 & - & - & 5 & 38.5 & - & - & 93 & 42.3 & - & - & - \\
\hline Previously treated for STIs & - & - & - & - & - & - & - & - & - & - & - & - & 0.839 \\
\hline No & 118 & 56.7 & - & - & 7 & 53.8 & - & - & 125 & 56.6 & - & - & - \\
\hline Yes & 90 & 43.3 & - & - & 6 & 46.2 & - & - & 96 & 43.4 & - & - & - \\
\hline
\end{tabular}

$\mathrm{STI}$, sexually transmitted infection; $\mathrm{CV}$, coefficient of variation.

\begin{tabular}{|c|c|}
\hline LA 088 & TGAAGACACCCGTTAGGCGCAACGGGACGGAGAGACCCCGTGAAGCTTTACTGTAGCTTA \\
\hline LA 202 & TGAAGACACCCGTTAGGCGCAACGGGACGGACAGACCCCGTGAAGCTTTACTGTAGCTTA \\
\hline LA 141 & TGAAGACACCCGTTAGGCGCAACGGGACGGGAAGACCCCGTGAAGCTTTACTGTAGCTTA \\
\hline G37 & TGAAGACACCCGTTAGGCGCAACGGGACGGAAAGACCCCGTGAAGCTTTACTGTAGCTTA \\
\hline V193 & -----ACACCCGTTAGGCGCAACGGGACGGAAAGACCCCGTGAAGCTTTACTGTAGCTTA \\
\hline V208 & - - - - - ACCCGTTAGGCGCAACGGGACGGAAAGACCCCGTGAAGCTTTACTGTAGCTTA \\
\hline V172 & 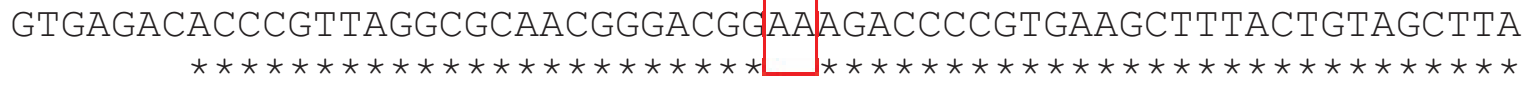 \\
\hline LA 088 & АTATTGATCAAAACACCACCATGTAGAGAATAGGTAGGA--------- \\
\hline LA202 & ATATTGATCAAAACACCACCATGTAGAGAATAGGTAGGA--ー-ー--- \\
\hline LA 141 & ATATTGATCAAAACACCACCATGTAGAGAATAGGTAGGA-------- \\
\hline G37 & АтАTтGATCAAАACACCACCATGTAGAGAATAGGTAGGAGCAATTGATGCAAGTTCGCAA \\
\hline V193 & 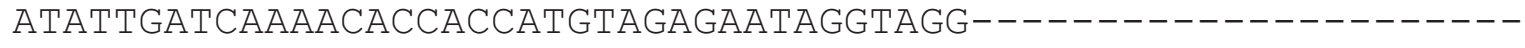 \\
\hline V20 08 & 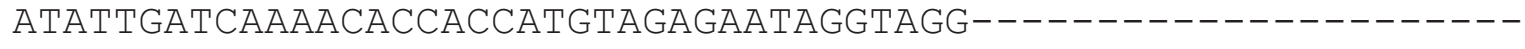 \\
\hline V172 & 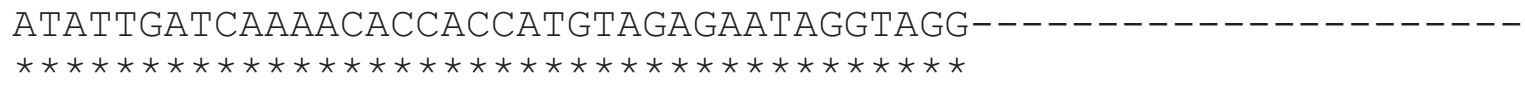 \\
\hline
\end{tabular}

Note: The red block shows the positions of the mutations.

FIGURE 1: Multiple sequence alignment of study samples (V172, V193 and V208) with strains of known mutations, LA141 (HF 572938.1 ), LA088 (HF 572933.1) and LA202 (HF 572946.1), and strain G37, which lacks the mutations.

women attending a primary health care clinic. In contrast, in the current study, no macrolide resistance-associated mutations for the $M$. genitalium positive samples were reported. Our results are similar to that obtained in a more recent study conducted in Johannesburg, South Africa by Muller et al. (2019). In that study, no macrolide resistanceassociated mutations were observed in their total study population of 266 stored M. genitalium positive isolates collected through the Gauteng STI National Microbiological Surveillance programme during the period 2007-2014. ${ }^{21}$ Similarly, Le Roux et al. (2018) reported no patterns of macrolide resistance amongst their $M$. genitalium positive isolates obtained in 2012 from pregnant women in Pretoria, South Africa. ${ }^{18}$ However, in that same study, the authors reported a macrolide resistance-associated mutation (A2059G) amongst their M. genitalium positive isolates obtained in 2016 . The same mutation was present in $25 \%$ of their isolates tested. There is a possibility that the A2059G mutation is prevalent in South African populations; however, this needs further investigation to provide conclusive evidence.

Despite the lack of resistance to macrolides in the studied population, continued antimicrobial resistance surveillance for M. genitalium in pregnant women will be important since azithromycin is now part of the South African national STI syndromic management guidelines for vaginal discharge syndrome.

The present study was limited in that samples were collected from pregnant women attending a single antenatal facility. However, the hospital from which the women were sampled in this study serves as a central hospital for women from around the Durban area, thereby making the population more 
generalised. The strength of this study is that we now provide prevalence data as well as data on macrolide susceptibility of M. genitalium in a population of pregnant women from KZN, an area of research that has received limited attention.

\section{Acknowledgements}

The authors thank all study participants as well as the antenatal clinic staff at the King Edward VIII Hospital, Durban.

\section{Competing interests}

The authors declare that they have no financial or personal relationships which may have inappropriately influenced them in writing this article.

\section{Authors' contributions}

All authors contributed equally to the work.

\section{Funding information}

The authors gratefully acknowledge the financial support from the National Research Foundation (Grant number 112080: Awarded to Dr Nathlee S. Abbai).

\section{Data availability statement}

The data that support the findings of this study are available from the corresponding author, upon reasonable request.

\section{Disclaimer}

The views and opinions expressed in this article are those of the authors and do not necessarily reflect the official policy or position of any affiliated agency of the authors.

\section{References}

1. Jensen JS. Mycoplasma genitalium: The aetiologic agent of urethritis and other sexually transmitted diseases. J Eur Acad Dermatol Venereol. 2004;18(1):1-11. https://doi.org/10.1111/j.1468-3083.2004.00923.x

2. Manhart LE, Critchlow CW, Holmes KK, et al. Mucopurulent cervicitis and Mycoplasma genitalium. J Infect Dis. 2003;187(4):650-657. https://doi.org/10.1086/367992

3. Taylor-Robinson D, Jensen JS. Mycoplasma genitalium: From Chrysalis to multicoloured butterfly. Clin Microbiol Rev. 2011;24(3):498-514. https://doi.org/10.1128/ CMR.00006-11

4. Cassell GH, Waites KB, Watson HL, Crouse DT, Harasawa R. Ureaplasma urealyticum intrauterine infection: Role in prematurity and disease in newborns. Clin Microbiol Rev. 1993;6(1):69-87. https://doi.org/10.1128/CMR.6.1.69

5. Taylor-Robinson D, Furr PM. Update on sexually transmitted mycoplasmas. Lancet. 1998;351(Suppl 1):S12-S15. https://doi.org/10.1016/S0140-6736(98)90004-6

6. Daxboeck F, Zitta S, Stadler M, Iro E, Krause R. Mycoplasma hominis and Ureaplasma urealyticum in patients with sterile pyuria. J Infect. 2005;51(1): 54-58. https://doi.org/10.1016/j.jinf.2004.06.010

7. Patai K, Szilágyi G, Hubay M, Szentmáriay IF, Paulin F. Severe endometritis caused by genital mycoplasmas after caesarean section. J Med Microbiol. 2005;54(12): 1249-1250. https://doi.org/10.1099/jmm.0.05457-0

8. Witt A, Berger A, Gruber CJ, et al. Increased intrauterine frequency of Ureaplasma urealyticum in women with preterm labor and preterm premature rupture of the membranes and subsequent cesarean delivery. Am J Obstet Gynecol. 2005;193(5):1663-1669. https://doi.org/10.1016/j.ajog.2005.03.067
9. Pararas MV, Skevaki CL, Kafetzis, DA. Preterm birth due to maternal infection: Causative pathogens and modes of prevention. Eur J Clin Microbiol Infect Dis. 2006;25(1):562-569. https://doi.org/10.1007/s10096-006-0190-3

10. Hitti J, Garcia P, Totten P, Paul K, Astete S, Holmes KK. Correlates of cervical Mycoplasma genitalium and risk of preterm birth among Peruvian women. Sex Trans Dis. 2010;37(2):81. https://doi.org/10.1097/OLQ.0b013e3181bf5441

11. Choi SJ, Park SD, Jang IH, Uh Y, Lee A. The prevalence of vaginal microorganisms in pregnant women with preterm labor and preterm birth. Ann Lab Med. 2012;32(3):194-200. https://doi.org/10.3343/alm.2012.32.3.194

12. Lis R, Rowhani-Rahbar A, Manhart LE. Mycoplasma genitalium infection and female reproductive tract disease: A meta-analysis. Clin Infect Dis. 2015;61(3):418-426. https://doi.org/10.1093/cid/civ312

13. Mavedzenge SN, Van Der Pol B, Weiss HA, et al. The association between Mycoplasma genitalium and HIV-1 acquistion in African women. AIDS. 2012;26(5):617-624. https://doi.org/10.1097/QAD.0b013e32834ff690

14. Vandepitte J, Weiss HA, Bukenya J, et al. Association between Mycoplasma genitalium infection and HIV acquisition among female sex workers in Uganda: Evidence from a nested case-control study. Sex Transm Infect. 2014;90(7):545-549. https://doi.org/10.1136/sextrans-2013-051467

15. Anderson B, Sokolowski I, Ostergaard L, Kjolseth Moller J, Olesen F, Jensen JS. Mycoplasma genitalium: Prevalence and behavioural risk factors in the general population. Sex Transm Infect. 2007:83(3):237-241. https://doi.org/10.1136/ sti.2006.022970

16. Weinstein SA, Stiles BG. A review of the epidemiology, diagnosis and evidencebased management of Mycoplasma genitalium. Sex Health. 2011;8(2):143-158. https://doi.org/10.1071/SH10065

17. Cazanave C, Manhart LE, Bebear C. Mycoplasma genitalium, an emerging sexually transmitted pathogen. Med Mal Infect. 2012;42(9):381-392. https://doi. org/10.1016/j.medmal.2012.05.006

18. Le Roux MC, Mafunise M, De Villiers BE, Ditsele RM. Antimicrobial susceptibility of Mycoplasma genitalium isolates from Pretoria, South Africa in 2012 and 2016. S Afr J Infect Dis. 2018;33(2):46-49. https://doi.org/10.4102/sajid.v33i2.17

19. Sexually Transmitted Infections Management Guidelines 2015. Adapted from: Standard treatment guidelines and essential drugs list PHC [homepage on the Internet] [cited 2019 Nov 24]. Available from: http://www.kznhealth.gov.za/ family/STI-guidelines-2015.pdf

20. Hay B, Dubbink $\mathrm{JH}$, Ouburg $\mathrm{S}$, et al. Prevalence and macrolide resistance of Mycoplasma genitalium in South African women. Sex Transm Dis. 2015;42(3): 140-142. https://doi.org/10.1097/OLQ.0000000000000246

21. Muller EE, Mahlangu MP, Lewis DA, Kularatne RS. Macrolide and fluoroquinoline resistance-associated mutations in Mycoplasma genitalium in Johannesburg South Africa, 2007-2014. BMC Infect Dis. 2019;19(1):148. https://doi. org/10.1186/s12879-019-3797-6

22. Jensen JS, Bradshaw CS, Tabrizi SN, Fairley CK, Hamasuna R. Azithromycin treatment failure in Mycoplasma genitalium-positive patients with nongonococcal urethritis is associated with induced macrolide resistance. Clin Infect Dis. 2008;47(12):1546-1553. https://doi.org/10.1086/593188

23. Manhart LE, Broad JM, Golden MR. Mycoplasma genitalium: Should we treat and how? Clin Infect Dis. 2011;53(Suppl 3):S129-S42. https://doi.org/10.1093/cid/ cir702

24. Manhart LE, Gillespie CW, Lowens MS, et al. Standard treatment regimens for nongonococcal urethritis have similar but declining cure rates: A randomized controlled trial. Clin Infect Dis. 2013;56(7):934-942. https://doi.org/10.1093/cid/ cis1022

25. Bissessor M, Tabrizi SN, Twin J, et al. Macrolide resistance and azithromycin failure in a Mycoplasma genitalium-infected cohort and response of azithromycin failures to alternative antibiotic regimens. Clin Infect Dis. 2015;60(8):1228-1236. failures to alternative antibiotic regimer
https://doi.org/10.1093/cid/ciu1162

26. Redelinghuys MJ, Ehlers MM, Dreyer AW, Lombaard HA, Kock MM. Prevalence of genital mycoplasmas and bacterial vaginosis in pregnant women in Gauteng, South Africa. Sex Transm Infect. 2013;89(Suppl 1):A159. https://doi.org/10.1136/ South Africa. Sex Transm Infect.
sextrans-2013-051184.0495

27. Abbai NS, Wand H, Ramjee G. Sexually transmitted infections in women participating in a biomedical intervention trial in Durban: Prevalence, coinfections, and risk factors. J Sex Trans Dis. 2013;2013:article 358402. https://doi. org/10.1155/2013/358402

28. Naidoo S, Wand H, Abbai NS, Ramjee, G. High prevalence and incidence of sexually transmitted infections among women living in KwaZulu-Natal, South Africa. AIDS Res Ther. 2014;11(1):article 31:1-7. https://doi.org/10.1186/1742 6405-11-31

29. Abbai NS, Wand H, Ramjee G. Socio-demographic and behavioural characteristics associated with HSV-2 sero-prevalence in high risk women in KwaZulu-Natal. BMC Res Notes. 2015;8:article 185:1-5. https://doi.org/10.1186/s13104-0151093-0

30. Abbai NS, Nyirenda M, Naidoo S, Ramjee G. Prevalent herpes simplex virus-2 increases the risk of incident bacterial vaginosis in women from South Africa. AIDS Behav. 2018;22(1):2172-2180. https://doi.org/10.1007/s10461-017-1924-1 


\section{Appendix 1}

TABLE 1-A1: Data from the sensitivity analysis of the 235 ribosomal ribonucleic acid conventional polymerase chain reaction when compared to the AziR assay (comparator assay) computed using R software (version 3.6.1).

\begin{tabular}{|c|c|c|c|c|}
\hline \multirow{2}{*}{$\begin{array}{l}\text { AziR assay (comparator assay): } \\
\text { Explanation }\end{array}$} & \multicolumn{4}{|c|}{ 23S PCR } \\
\hline & Element & Estimate & Lower & Upper \\
\hline $\begin{array}{l}\text { Apparent (test or predicted) } \\
\text { prevalence }(+)\end{array}$ & APREV & 0.615 & 0.316 & 0.861 \\
\hline True (outcome) prevalence $(+)$ & TPREV & 0.846 & 0.546 & 0.981 \\
\hline $\begin{array}{l}\text { Sensitivity (correct [+] in } \\
\text { diseased) }\end{array}$ & SE & 0.545 & 0.234 & 0.833 \\
\hline $\begin{array}{l}\text { Specificity (correct [-] in not } \\
\text { diseased) }\end{array}$ & SP & 0.000 & 0.000 & 0.842 \\
\hline $\begin{array}{l}\text { Diagnostic accuracy (total } \\
\text { correct }[+] \text { and }[-] \text { ) }\end{array}$ & DIAG.ACC & 0.462 & 0.192 & 0.749 \\
\hline $\begin{array}{l}\text { Diagnostic OR (likely correct } \\
{[+] \text { in diseased) }}\end{array}$ & DIAG.OR & 0.000 & 0.000 & - \\
\hline $\begin{array}{l}\text { Number needed to diagnose } \\
\text { (to give one }[+] \text { ) }\end{array}$ & NND & -2.200 & -1.305 & 1.483 \\
\hline $\begin{array}{l}\text { Youden's index (max true } \\
{[+] \text { without false }[+] \text { ) }}\end{array}$ & YOUDEN & -0.455 & -0.766 & 0.674 \\
\hline PPV (genuinely diseased in [+]) & PPV & 0.750 & 0.349 & 0.968 \\
\hline $\begin{array}{l}\text { NPV (genuinely not diseased } \\
\text { in [-]) }\end{array}$ & NPV & 0.000 & 0.000 & 0.522 \\
\hline LR+ (true $[+]$ to one false $[+]$ ) & PLR & 0.545 & 0.318 & 0.936 \\
\hline LR- (false [-] to 10 true [-]) & NLR & - & - & - \\
\hline $\begin{array}{l}\text { Proportion of subjects with } \\
\text { the outcome ruled out }\end{array}$ & PRO & 0.385 & 0.139 & 0.684 \\
\hline $\begin{array}{l}\text { Proportion of subjects with } \\
\text { the outcome ruled in }\end{array}$ & PRI & 0.615 & 0.316 & 0.861 \\
\hline Proportion of false (+) & PFP & 1.000 & 0.158 & 1.000 \\
\hline Proportion of false (-) & PFN & 0.455 & 0.167 & 0.766 \\
\hline $\begin{array}{l}\text { Agreement beyond one } \\
\text { expected by chance alone }\end{array}$ & KAPPA & -0.282 & -0.736 & 0.173 \\
\hline Dichotomous correlation & $\mathrm{PHI}$ & -0.200 & - & - \\
\hline $\begin{array}{l}\text { Equivalent continuous scale } \\
\text { correlation }\end{array}$ & TETRACHORIC & -0.386 & - & - \\
\hline $\begin{array}{l}\text { Non and diseased } \\
\text { discrimination ability (z-score) }\end{array}$ & D'PRIME & -0.727 & - & - \\
\hline Human interpretation bias & CRITERION & -0.842 & - & - \\
\hline $\begin{array}{l}\text { Average sensitivity for all } \\
\text { specificity values }\end{array}$ & AUC & 0.304 & - & - \\
\hline $\begin{array}{l}\text { Test for presence of bias } \\
\text { (systematic difference) }\end{array}$ & MCNEMAR & $p=0.257$ & - & - \\
\hline
\end{tabular}

PCR, polymerase chain reaction; PPV, positive predictive value; NPV, negative predictive value; APREV, apparent prevalence; TPREV, true prevalence; DIAG.ACC, diagnostic accuracy; DIAG.OR, diagnostic odds ratio; PLR, positive log ratio; NLR, negative log ratio; SE, sensitivity; $\mathrm{SP}$, specificity; NND, number needed to diagnose; PRO, proportion ruled out; PRI, proportion ruled in; PFP, proportion of false positives; PFN, proportion of false negatives; AUC, Area under the curve.

TABLE 2-A1: Data obtained for the clinical samples using the Allplex ${ }^{\mathrm{TM}}$ MG \& AziR assay (Seegene): Output obtained directly from the Seegene viewer linked to the Bio-Rad CFX96 instrument.

\begin{tabular}{|c|c|c|c|c|c|c|c|c|c|c|c|c|c|c|c|c|c|c|c|}
\hline \multirow[t]{2}{*}{ Well } & \multirow[t]{2}{*}{ Name } & \multirow[t]{2}{*}{ Type } & \multicolumn{4}{|c|}{ FAM } & \multicolumn{4}{|c|}{ HEX } & \multicolumn{4}{|c|}{ Cal Red 610} & \multicolumn{2}{|c|}{ Quasar 670} & \multicolumn{2}{|c|}{ Quasar 670} & \multirow[t]{2}{*}{ Auto Interpretation } \\
\hline & & & A2059T & $C(t)$ & A2058T & $C(t)$ & A2058C & $C(t)$ & A2058G & $C(t)$ & A2059C & $C(t)$ & A2059G & $C(t)$ & MG & $C(t)$ & IC & $C(t)$ & \\
\hline A01 & V014 & SAMPLE & - & N/A & - & N/A & - & $\mathrm{N} / \mathrm{A}$ & - & N/A & - & $\mathrm{N} / \mathrm{A}$ & - & $\mathrm{N} / \mathrm{A}$ & - & $\mathrm{N} / \mathrm{A}$ & + & 29.32 & - \\
\hline B01 & V019 & SAMPLE & - & $\mathrm{N} / \mathrm{A}$ & - & N/A & - & N/A & - & N/A & - & N/A & - & NIA & + & 37.12 & + & 26.19 & MG \\
\hline $\mathrm{C} 01$ & V055 & SAMPLE & - & N/A & - & N/A & - & N/A & - & N/A & - & N/A & - & NIA & + & 34.90 & + & 26.72 & MG \\
\hline D01 & V069 & SAMPLE & - & $\mathrm{N} / \mathrm{A}$ & - & N/A & - & $\mathrm{N} / \mathrm{A}$ & - & N/A & - & $\mathrm{N} / \mathrm{A}$ & - & NIA & - & N/A & + & 28.60 & - \\
\hline E01 & V083 & SAMPLE & - & N/A & - & N/A & - & N/A & - & $\mathrm{N} / \mathrm{A}$ & - & N/A & - & NIA & + & 35.71 & + & 28.31 & MG \\
\hline F01 & V103 & SAMPLE & - & N/A & - & N/A & - & $\mathrm{N} / \mathrm{A}$ & - & $\mathrm{N} / \mathrm{A}$ & - & N/A & - & NIA & + & 32.07 & + & 25.13 & MG \\
\hline G01 & V104 & SAMPLE & - & N/A & - & $\mathrm{N} / \mathrm{A}$ & - & N/A & - & N/A & - & N/A & - & NIA & + & 30.11 & + & 25.00 & MG \\
\hline H01 & V109 & SAMPLE & - & $\mathrm{N} / \mathrm{A}$ & - & N/A & - & $\mathrm{N} / \mathrm{A}$ & - & N/A & - & N/A & - & NIA & + & 34.57 & + & 25.64 & MG \\
\hline A12 & V193 & SAMPLE & - & N/A & - & N/A & - & N/A & - & N/A & - & N/A & - & NIA & + & 26.33 & + & 25.07 & MG \\
\hline B12 & V172 & SAMPLE & - & $\mathrm{N} / \mathrm{A}$ & - & N/A & - & N/A & - & N/A & - & $\mathrm{N} / \mathrm{A}$ & - & NIA & + & 26.25 & + & 22.96 & MG \\
\hline C12 & V197 & SAMPLE & - & N/A & - & N/A & - & N/A & - & $\mathrm{N} / \mathrm{A}$ & - & N/A & - & NIA & + & 37.96 & + & 22.97 & MG \\
\hline D12 & V208 & SAMPLE & - & $\mathrm{N} / \mathrm{A}$ & - & N/A & - & N/A & - & N/A & - & N/A & - & NIA & + & 26.50 & + & 23.59 & MG \\
\hline E12 & V238 & SAMPLE & - & N/A & - & N/A & - & N/A & - & $\mathrm{N} / \mathrm{A}$ & - & $\mathrm{N} / \mathrm{A}$ & - & NIA & + & 35.29 & + & 27.30 & MG \\
\hline G12 & $\mathrm{NC}$ & $\mathrm{NC}$ & - & $\mathrm{N} / \mathrm{A}$ & - & N/A & - & $\mathrm{N} / \mathrm{A}$ & - & $\mathrm{N} / \mathrm{A}$ & - & $\mathrm{N} / \mathrm{A}$ & - & N/A & - & $\mathrm{N} / \mathrm{A}$ & - & $\mathrm{N} / \mathrm{A}$ & Negative Control(-) \\
\hline
\end{tabular}

N/A, not applicable; FAM, fluorescein amidite; HEX, hexachlorofluorescein; PS, positive control; NC, negative control. 